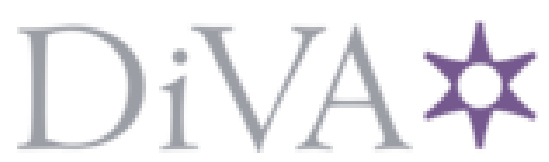

http://www.diva-portal.org

This is the published version of a paper published in Journal of Climate.

Citation for the original published paper (version of record):

Jönsson, K., Nilsson, C. (2009)

Scots pine (pinus sylvestris L.) on shingle fields: a dendrochronologic reconstruction of early summer precipitation in mideast Sweden.

Journal of Climate, 22(17): 4710-4722

http://dx.doi.org/10.1175/2009JCLI2401.1

Access to the published version may require subscription.

N.B. When citing this work, cite the original published paper.

Permanent link to this version:

http://urn.kb.se/resolve?urn=urn:nbn:se:umu:diva-52232 


\title{
Scots Pine (pinus sylvestris L.) on Shingle Fields: A Dendrochronologic Reconstruction of Early Summer Precipitation in Mideast Sweden
}

\author{
KARIN JÖNSSON \\ Department of Natural Sciences, Mid Sweden University, Sundsvall, Sweden \\ CHRISTER NILSSON \\ Landscape Ecology Group, Department of Ecology and Environmental Science, Umeå University, Umeå, Sweden
}

(Manuscript received 3 January 2008, in final form 20 February 2009)

\begin{abstract}
Scots pine (Pinus sylvestris L.) trees growing on shingle fields offer a unique possibility to reconstruct precipitation and study climate variability in the fairly humid eastern part of central Sweden. Tree-ring characteristics were compared with monthly (1890-2001) and daily (1961-2001) climate data from an adjacent meteorological station. Chronologies for latewood (LW), earlywood (EW), and tree-ring widths (RW) were constructed from 73 living and dead trees. Correlation analyses show that tree growth is most sensitive to early summer precipitation. EW shows the strongest correlation with precipitation in May and June while LW is best correlated with June and July precipitation. A reconstruction model for May-June precipitation was calculated using principal component analysis (PCA) regression (regular regression) including EW, LW, and RW for present and previous years. The model explained $46 \%$ of the variation in May-June precipitation and allowed a reconstruction back to 1560 . Information about wet and dry years was collected from historical documents and was used to validate the result. Periods with precipitation above and below the mean show agreement with previous reconstructions of spring precipitation from tree rings in Finland and of spring floods from estuary sediments in the region. Analyses of correlations between meteorological stations and reconstructed precipitation show that the model is valid for the coastal part of central Sweden. The authors conclude that Scots pine trees on shingle fields are well suited for precipitation reconstruction, and the separate analyses of LW and EW improve the reconstruction.
\end{abstract}

\section{Introduction}

Global surface temperature has increased by $0.76^{\circ} \mathrm{C} \pm$ $0.19^{\circ} \mathrm{C}$ during the last century (Solomon et al. 2007) and by as much as $0.6^{\circ} \mathrm{C}$ within the last three decades (Hansen et al. 2006). This increase in temperature has been accompanied by changes in the hydrologic cycle (Solomon et al. 2007). There is, however, much uncertainty in evaluations of precipitation change. Instrumental data are used to improve the understanding of climate systems and climate models of future climate scenarios. The $100-150 \mathrm{yr}$ of available instrumental meteorological data are not enough to study long-term fluctuations in climate. Jansen et al. (2007) stated that

Corresponding author address: Karin Jönsson, Department of Natural Sciences, Mid Sweden University, SE-851 70 Sundsvall, Sweden.

E-mail: karin.jonsson@miun.se paleoclimate data are the key to evaluating the ability of climate models to simulate realistic climate change. Climate fluctuations in the past have been recorded in environmental archives and substantially added to the instrumental records. For example, fluctuations in glacier size (Karlén 1973; Grove and Switzur 1994; Bakke et al. 2005; Nesje 2005) and bog formation speed (Borgmark and Schoning 2005; De Jong et al. 2006) provide information about climate in a long-term perspective, whereas ice layers (O'Brien et al. 1995), lake sediments (Sander 2003; Zillén 2003; Bjune et al. 2005), tree rings (Briffa et al. 1992; Lindholm and Eronen 2000), and corals (Linsley et al. 1994) can inform about short-term variation. Networks of high-resolution paleodata have proven useful for studies of temperature patterns in the Northern Hemisphere (Mann et al. 1998). Information about climate variability can also be extracted from historical records (e.g., Pfister et al. 1999; Gimmi et al. 2007) and used both for reconstructions 
(Kastellet et al. 1998; Brázdil et al. 2005) and for independent verification of existing models (Linderholm and Molin 2005).

Studies of the relationship between tree rings and climate (dendroclimatology) can indicate climate variations in the past because of the yearly information contained in tree rings. The characteristics of a tree ring (such as ring width, density, and number of resin ducts) are affected by an age-related growth trend, climate during present and previous years, disturbance on an individual tree level (e.g., a change in competition), and disturbance on the stand/population level (such as fire and insect outbreaks) (Schweingruber 1988; Cook and Kairiukstis 1990). To reveal useful climate information from tree rings, the magnitude and frequency of such nonclimatic disturbance effects should be minimized. Therefore, sample replication and site selection are vital in dendroclimatologic studies.

Tree growth at very cold sites will generally correspond to temperature, whereas at very dry sites it will reflect precipitation (Fritts 1976; Cook and Kairiukstis 1990). By comparing tree-ring characteristics with climate parameters from the instrumental period, a model can be built and used for climate reconstruction purposes. In the Nordic countries several tree-ring chronologies have been constructed for high altitudes and latitudes. Several authors have successfully used these chronologies to reconstruct summer temperatures (Briffa et al. 1992; Jones et al. 1998; Kaalela-Brundin 1999; Kirchhefer 2001; Gunnarson and Linderholm 2002; Helama et al. 2002; Linderholm and Gunnarson 2005; Grudd 2006). Thanks to these reconstructions, knowledge of past climate variations in Scandinavian mountains has improved during the last decades.

Lindholm et al. (2000) compared trees from different latitudes in Finland and found that Scots pine growing at lower latitudes was less affected by temperature and more affected by precipitation during the growing season. They also found that the relationship between climate and diameter growth of pine trees became weaker toward the south. Trees in Sweden are generally not limited by precipitation and tree rings have been considered to be of limited use for reconstructing precipitation (Erlandsson 1936; Eklund 1954). Therefore, there are only a few investigations comparing these variables. Linderholm et al. (2004) studied Scots pine on dry sites in southern Sweden and found that $30 \%$ of the variation in precipitation in May and June could be explained by ring-width data. Linderholm et al. (2002) compared climate and growth response patterns for pine trees growing on peatland and dry sites, respectively. They concluded that growth of peatland trees was correlated with climate but not suitable for high-frequency recon- structions of single climate parameters. Helama and Lindholm (2003) reconstructed May-June precipitation in southeastern Finland and were able to capture $31 \%$ of the variance in the observed precipitation record.

In this study we focused on the possibility to extract information about precipitation variability from Scots pine in the mideast part of Sweden (Fig. 1). Study sites were chosen to minimize the impact of internal and external disturbances, thus maximizing the effect of precipitation. Two sites were selected on shingle fields (i.e., areas with more or less thick layers of sorted, coarse, stone and boulder material) with very low water-holding capacity. Scots pine trees growing on these shingle fields were therefore hypothesized to respond to variation in water supply. Typically, trees growing on shingle fields are solitary, and intraspecific competition is assumed to be negligible. In this article we use climate-growth relationships from this dry habitat to make the first precipitation reconstruction ever in this fairly humid region.

\section{Material and methods}

\section{a. Sample sites}

The study was conducted on shingle fields in two nature reserves (Smitingen and Vårdkasmalen) on Härnön in mideast Sweden (Fig. 1). The sites are located at 20 and $135 \mathrm{~m}$ MSL, respectively. Since the end of the latest glaciation, about 10400 B.C.E., this region has experienced an isostatic rebound. Today the land uplift is $7.8 \mathrm{~mm} \mathrm{yr}^{-1}$ (Lundqvist 1987). Sites below the former highest coastline have been exposed to more or less extensive wave erosion. Bare rocks and wave-washed soils such as shingle fields are common. The sparse vegetation is dominated by drought tolerant lichens. Pine trees are typically low and solitary. Wood productivity is below $1 \mathrm{~m}^{3} \mathrm{ha}^{-1} \mathrm{yr}^{-1}$ and the shingle fields are therefore protected from forestry by the Swedish Forestry Act [Svensk Författningssamling (SFS) 1979:429]. The mean temperature in the area $(1961-90)$ is $3.9^{\circ} \mathrm{C}$ and the precipitation is $700 \mathrm{~mm}$ (about $35 \%$ of which is snow; Bergström 1994). The growing season defined as the period when the 24-h average temperature exceeds $5^{\circ} \mathrm{C}$ (Lundmark 1986) was on average 162 days (7 May13 October) 1961-90 [Swedish Meteorological and Hydrological Institute (SMHI)]. The area is considered weakly humid because precipitation is greater than evapotranspiration during the growing season (see climograph in Fig. 1).

\section{b. Sampling and chronology building}

Solitary Scots pine trees with straight trunks were selected for sampling. Local moist patches on the shingle 


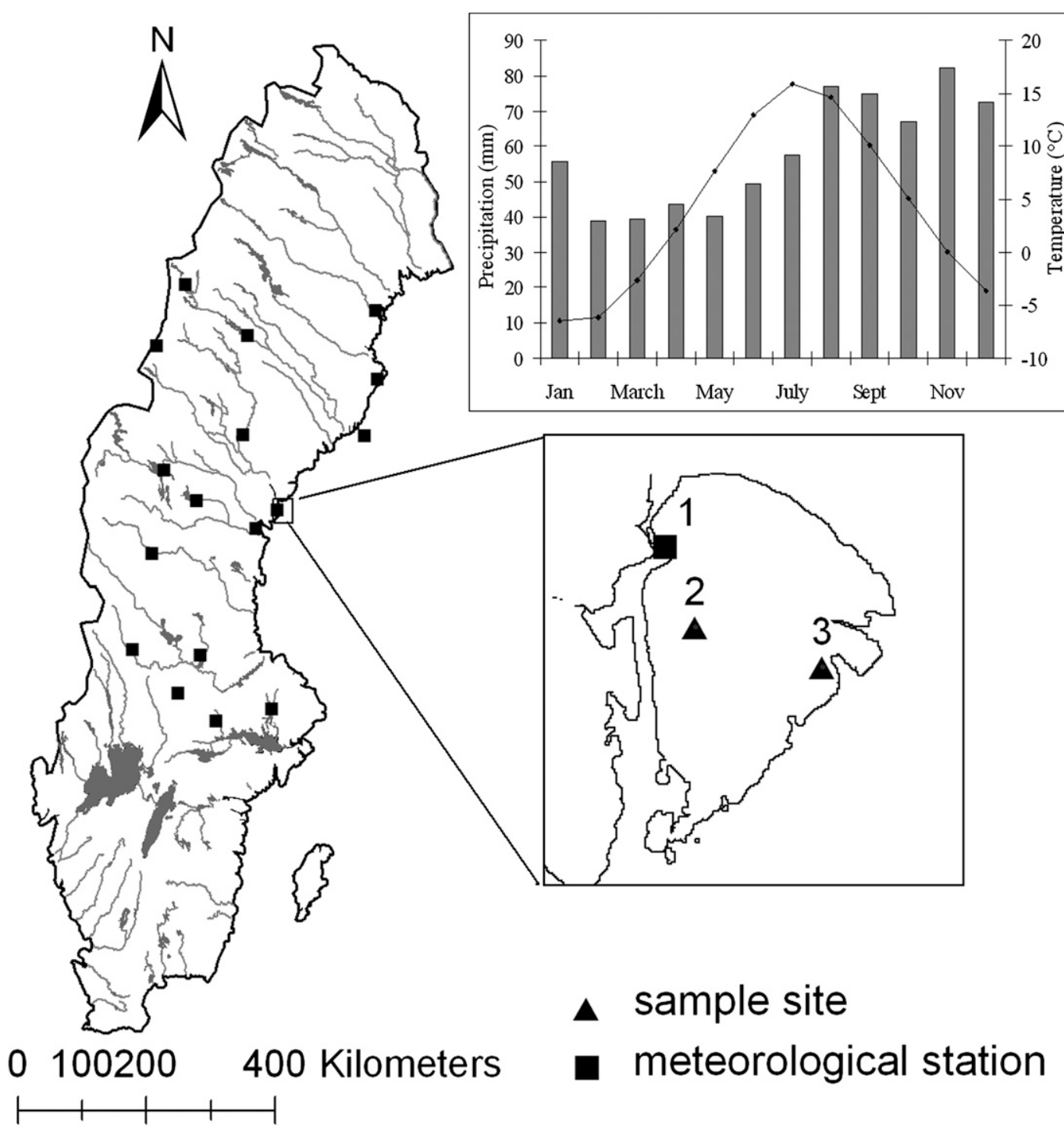

FIG. 1. Meteorological station in (1) Härnösand, central Sweden, and study sites at (2) Vårdkasen and (3) Smitingen. (top right) A climograph (bars show precipitation and the line shows temperature) for Härnösand meteorological station.

fields, indicated by mosses and shrubs, were avoided. Living trees and standing dead trees were sampled with an increment corer $(5.15 \mathrm{~mm})$. At least two cores were taken from each tree at breast height $(1.3 \mathrm{~m})$. Small cookies or wedges were taken from stumps and downed trees with a saw. Diameter at breast height, understory, and position in the shingle field were noted for each tree. The wood cores were mounted on wooden sticks and their surface was cut with a razor blade and polished with chalk to enhance the contrast between earlywood (EW) and latewood (LW). EW and LW were measured separately with a resolution of $0.01 \mathrm{~mm}$. Anatomical characteristics (reaction wood, color, and presence of resin ducts) were noted for each ring.
Chronologies were built following the procedure explained by Fritts (1976). Two radii from each tree were compared and cross dated toward the mean chronology and existing chronologies from the same region (Schweingruber 2005; Larsson 2006). The programs COFECHA (Holmes et al. 1986) and CDendro 5.3 (available online at www.cybis.se) were used for cross dating. Cross correlations in COFECHA and CDendro show mismatches and possible problems. Although sites were selected to minimize internal variation and external influences, standardization is needed to separate the climate signal from the impact of tree aging. There are several ways of solving this problem and maintaining as much as possible of the low-frequency variation (e.g., 
Fritts 1976; Cook and Kairiukstis 1990; Helama and Lindholm 2003). In this study, two radii from each tree were averaged to create mean-tree series and chronologies were built using mean trees. A linear regression (any slope; 28 trees) or a negative exponential curve (45 trees) was automatically chosen to remove the agerelated growth trend before building the chronology.

The Auto-Regressive Standardization (ARSTAN) program (Cook 1985; Cook and Krusic 2005) was used for chronology building. Chronologies were built for EW, $\mathrm{LW}$, and the whole ring width (RW). ARSTAN produces three different chronologies: one standard chronology (STD) with averaged, standardized series; one residual chronology (RES) where autocorrelation is removed from each individual series to receive a strong common signal; and one ARSTAN chronology (ARS) in which the pooled autocorrelation is reintroduced into the measurement series for maximum low-frequency variability (Holmes et al. 1986). The chronologies were tested with programs COFECHA and ARSTAN. ARSTAN also gives statistical information of the quality of the tested chronology. The mean correlation between all possible pairs of indexed series within the population (Rbar) is used as a measure of the common signal within the chronology (Wigley et al. 1984; Briffa and Jones 1990). The expressed population signal (EPS) is a frequently used tool in estimating the chronology quality. EPS is a function of Rbar and sample size and was used to define the reliable part of the chronologies (EPS $>0.85$ ) following Wigley et al. (1984) and Briffa (1995).

\section{c. Climate data}

Climate data were obtained from SMHI. Monthly meteorological data are available for the meteorological station in Härnösand $\left(62^{\circ} 37^{\prime} \mathrm{N}, 17^{\circ} 56^{\prime} \mathrm{E}\right)$ from 1859 (precipitation) and 1787 (temperature, continuous from 1859). Daily data are available from 1961 . Quality control of monthly temperature and precipitation data has previously been done by the North Atlantic Climate Database (NACD) (Tuomenvirta et al. 2001). Precipitation data were used from 1890 to 2001 to avoid missing values. Meteorological data from other NACD stations (Fig. 1) were used for comparison. Monthly and seasonal indices of North Atlantic Oscillation (NAO) were provided by Hurrell (1995) and the reconstructed winter NAO index by Cook et al. (2002).

\section{d. Climate-growth analyses and reconstruction models}

Relationships between climate and tree-ring data were analyzed with the program Dendroclim2002 (Biondi and Waikul 2004). It uses bootstrapping for calculation of correlation and response functions. STD, ARS, and RES chronologies for tree-ring parameters (RW, EW, and LW) were compared with temperature and precipitation for each month and different combinations of months during the year of growth $(t)$ and three previous years $(t-1, t-2, t-3)$. Precipitation data are not normally distributed and are therefore expressed as logarithms $(\lg \mathrm{P})$.

Since the tree-ring parameters are intercorrelated, the reconstruction model was calculated using principal component analysis (PCA). The use of this method in dendroclimatology is discussed in Fritts (1976) and Fritts and Guiot (1990). The reconstruction model was verified by splitting the data into two periods (1890-1945 and 1946-2001). The first period was used for correlation and the second period for verification (early calibration) and vice versa (late calibration) (Fritts and Guiot 1990). Mean squared error (MSE), reduction of error (RE), coefficient of efficiency (CE), and the squared correlation $\left(r^{2}\right)$ were used to assess the accuracy of the reconstruction (National Research Council 2006). MSE shows how close the calculated values are to the actual values. RE statistics compare the MSE with the result from a reconstruction where the mean precipitation (May-June) during the calibration period is used as predicted value for each year of the calibration period. CE compares MSE with a constant reconstruction that depends on the validation data instead. Correlations between tree growth parameters and precipitation data from meteorological stations in a larger area (Fig. 1) were calculated in order to evaluate the validity of the reconstruction in a larger region.

\section{e. Historical data}

One way to verify reconstructed precipitation is to compare results with historical records. We collected information from travel documentation, governmental documents, newspapers, and books (Eriksson 1919; SMHI 1924, 1993; Burman 1930; Post 1984; Högman 2005; Jonsson 2005; Törnlöv 2005). Years with extreme weather are often reported in such documents because they can be associated with bad crop harvest. Before the instrumental period, most of the food was locally produced and before railways were built in the late nineteenth century the society was vulnerable to agricultural failures. In the written archives, specific years can be referred to as cold, warm, dry, or wet. In this study we tried to separate information directly correlated to precipitation, that is, years described as wetter or drier than normal during the growing season. We included information like "years with bad harvest" even though it can refer to severe night frost as well as too much or too little precipitation. Bad harvest may also be caused by low seed quality due to previous bad harvest 

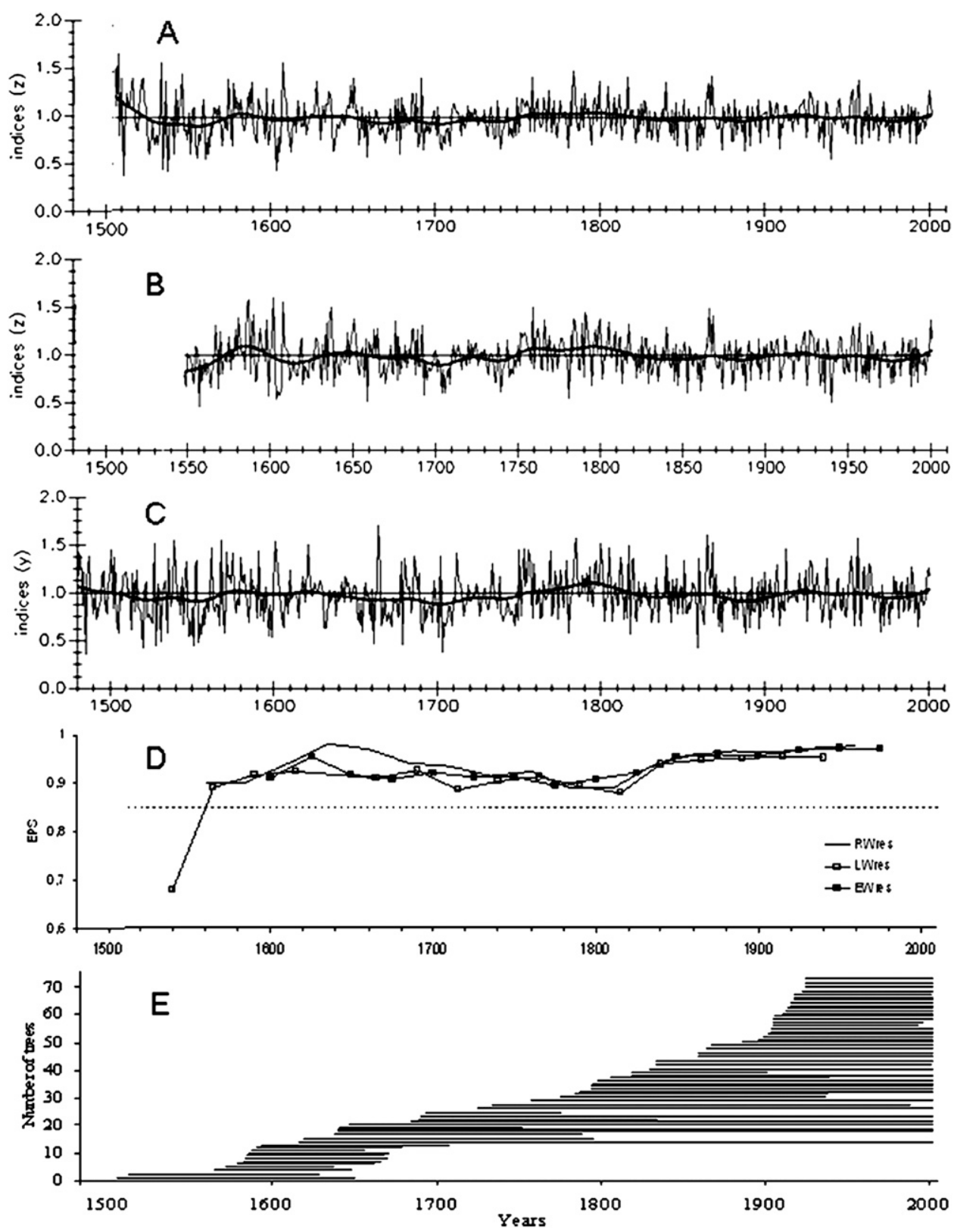

FIG. 2. (a)-(c) The RES chronology, derived from the ARSTAN program, for RW, EW, and LW. (d) The running EPS that was used to define the reliable part of the chronology (EPS $>0.85$ ) following Wigley et al. (1984) and Briffa (1995). (e) The number of trees in the chronology and the age overlap between them.

years. The gathered information was grouped into wet years, dry years, and years with bad harvest.

\section{Results}

\section{a. Chronologies}

After excluding trees growing close to the outer limit of the shingle fields because of low correlation with the master chronology, 73, 69, and 69 trees were incorporated in the $\mathrm{RW}, \mathrm{EW}$, and $\mathrm{LW}$ chronologies, respectively (Fig. 2). Chronology characteristics are given in Table 1. No missing rings were found in the series used in the chronology. The calculated EPS signal indicates that the number of trees contributing to the chronology is sufficient from 1560 (Fig. 2d). The number increases after 1590 (Fig. 2e) giving an even more reliable chronology. 
TABLE 1. Summary of the chronology characteristics for the earlywood, latewood, and ring-width chronologies. Mean sensitivity is a measure of the relative change in ring widths from one year to the next.

\begin{tabular}{lccccc}
\hline \hline Chronology & $\begin{array}{c}\text { No. } \\
\text { of trees }\end{array}$ & $\begin{array}{c}\text { Mean } \\
\text { width } \\
(\mathrm{mm})\end{array}$ & $\begin{array}{c}\text { Mean } \\
\text { sensitivity }\end{array}$ & $\begin{array}{c}\text { Rbar } \\
\text { Reliable } \\
\text { EPS }>0.85\end{array}$ \\
\hline Ring width & 73 & 0.73 & 0.266 & 0.383 & $1560-2001$ \\
Earlywood & 69 & 0.48 & 0.292 & 0.384 & $1548-2001$ \\
Latewood & 69 & 0.25 & 0.351 & 0.383 & $1560-2001$ \\
\hline
\end{tabular}

\section{b. Climate-growth analyses}

The RES chronologies had stronger correlations with climate parameters than STD and ARS chronologies. The precipitation in May showed the best correlation with EW and the precipitation in July with LW. Both EW and LW chronologies were significantly $(p<0.05)$ correlated with June precipitation. The precipitation in June was therefore split into two parts (days 1-15 and 16-30). This was only possible for the period 1961-2002 for which daily data are available. These periods are better correlated with the EW P(1 May-15 June); $r=0.56, p<0.001$ and LW P(16 June-31 July); $r=0.66$, $p<0.001$ chronologies suggesting that LW formation in this region is affected by climate in the second half of June (Table 2). The only significant correlations between chronologies and temperature were negative and were found in June for EW and RW and in June and July for LW (Table 2). No relationship was found between number of resin ducts and climate parameters.

\section{c. Reconstruction of precipitation}

The climate-growth analyses show that precipitation in May, June, and, less pronounced, July had the highest influence on growth of pine trees. Because of the short period with available data for daily precipitation, monthly precipitation data for May and June were combined and used in further analyses. RES chronologies showed best correlations with climate data and were used in further analyses. Loadings of the tree-ring parameters included in the PCA analyses are shown in Table 3. Principal components 1, 2 and 3 (PC1, PC2, and PC3) explained 86.6\% of the variation and were used in the regression. The final model (Table 3) explained $46 \%$ of the variation in MayJune precipitation (Fig. 3). Results from the verification tests are shown in Table 3. The positive values on $\mathrm{CE}$ and $\mathrm{RE}$ together with the late and early calibrations indicate that the reconstructed values provide valuable information of past spring precipitation.

The 10-yr running mean curve (Fig. 4) shows a period with low precipitation between years 1560 and 1590 . This period is followed by a period with annual precipitation values mostly above mean, but with more variability, before the next low-precipitation periods $1657-75$ and 1694-1751. During the period 1753-1832 the annual precipitation amounts were mostly higher than average. From the middle of the nineteenth century to the present annual precipitation values were relatively stable but with frequent small variations around the mean value. Correlations between the reconstructed MayJune precipitation for Härnösand and other meteorological stations show that the reconstruction model produced results that were meaningful for a major part of mideast Sweden (Fig. 5). Comparisons between reconstructed May-June precipitation and indices explaining Arctic Oscillation (AO) (D'Arrigo et al. 2003) and NAO (Hurrell 1995; Cook et al. 2002) showed no significant correlations between year-to-year variations.

\section{d. Historical data}

The comparison with written historical information shows that reported dry years are consistent with years

TABLE 2. Significant bootstrapped correlation functions $(p<0.05)$ between the chronologies and average monthly temperature and precipitation during 1890-2001. Year $t$ represents the year of growth and year $t-1$ represents the previous year. Precipitation for AprilAugust has been averaged in different ways to examine the relationship between growth and periods longer than one month. Daily precipitation data (1961-2001) were used to calculate precipitation between 1 May and 15 Jun and 16 Jun and 31 Jul.

\begin{tabular}{|c|c|c|c|c|c|c|c|c|c|c|c|c|c|c|c|c|}
\hline & \multicolumn{6}{|c|}{ Precipitation $(t-1)$} & \multicolumn{10}{|c|}{ Precipitation $(t-1)$} \\
\hline & May & Jun & Jul & Aug Sep & $\mathrm{p} \quad$ Oct & Nov Dec & Jan $\mathrm{F}$ & eb Mar & Apr & May J & Jun & Jul Aug & Sep & Oct & Nov & Dec \\
\hline RW & & -0.19 & & 0.22 & & & & & & $0.27 \quad 0$ & 0.58 & & & & & \\
\hline EW & & -0.18 & & 0.23 & & & & & & 0.330 & 0.52 & & & & & \\
\hline \multirow[t]{3}{*}{ LW } & & & & 0.18 & & & & & & & 0.47 & 0.28 & & & & \\
\hline & \multicolumn{12}{|c|}{ Precipitation $(t)$} & \multicolumn{4}{|c|}{ Temperature $(t)$} \\
\hline & May-Jur & un May & $-\mathrm{Jul}$ & May-Aug & Jun-Jul & Jun-Aug & Apr-Jun & Apr-Aug & $1 \mathrm{Ma}$ & ay-15 Jun & in 16 & Jun-31 Jul & May & Jun & Jul & Aug \\
\hline RW & 0.58 & 0.4 & & 0.37 & 0.39 & 0.28 & 0.50 & 0.36 & & 0.49 & & 0.38 & & -0.28 & & \\
\hline EW & 0.57 & 0.3 & & 0.33 & 0.25 & 0.22 & 0.51 & 0.34 & & 0.56 & & & & -0.30 & & \\
\hline LW & 0.38 & 0.4 & & 0.39 & 0.51 & 0.39 & 0.31 & 0.34 & & & & 0.66 & & -0.14 & -0.17 & \\
\hline
\end{tabular}


TABLE 3. Summary of PCA and regression statistics for the equations predicting spring precipitation in May-June. Verification statistics show explained variance during the calibration period $R^{2}$; squared correlation coefficient over the verification period $r^{2}$; MSE; RE; and CE. The final regression equation is presented along with the loadings for each principal component included in the equation.

\begin{tabular}{|c|c|c|c|c|c|}
\hline Calibration/verification period & $R^{2}(p<0.001)$ & $r(p<0.001)$ & MSE & $\mathrm{RE}$ & $\overline{\mathrm{CE}}$ \\
\hline 1890-1945/1946-2001 & 0.58 & 0.70 & 0.020 & 0.52 & 0.25 \\
\hline 1946-2001/1890-1945 & 0.37 & 0.59 & 0.017 & 0.82 & 0.44 \\
\hline 1890-2001 (calculated/measured values) & 0.46 & 0.674 & 0.019 & & \\
\hline Regression equation 1890-2001 & \multicolumn{5}{|c|}{$\lg \mathrm{P}_{(\text {May June) }}=1.94-0.0681$ PCA1 +0.0389 PCA2-0.0314 PCA3 } \\
\hline Loadings & PCA1 & & PCA2 & & PCA3 \\
\hline $\mathrm{RW}_{(t)}$ & -0.449 & & 0.444 & & -0.093 \\
\hline $\mathrm{EW}_{(t)}$ & -0.438 & & 0.388 & & -0.373 \\
\hline $\mathrm{LW}_{(t)}$ & -0.339 & & 0.379 & & 0.598 \\
\hline $\mathrm{RW}_{(t+1)}$ & 0.465 & & 0.426 & & 0.090 \\
\hline $\mathrm{EW}_{(t+1)}$ & 0.410 & & 0.418 & & 0.366 \\
\hline $\mathrm{LW}_{(t+1)}$ & 0.327 & & 0.391 & & -0.593 \\
\hline
\end{tabular}

when precipitation predicted from tree-ring data was below mean, and reported wet years coincided with predicted precipitation above mean. We found information about six dry years and eight wet years in the historical records. Even if the number of years is low, we compared the calculated precipitation during these years. A two-sample $t$ test showed that the two groups were significantly different from each other according to mean (65.2 and 123.4) and variance (212.7 and 658.1). This cannot be regarded as proof of a valid reconstruction, but there is nothing in the historical information that contradicts our precipitation reconstruction.

\section{Discussion}

\section{a. Climate-growth relationships}

Strong correlations between chronologies and early summer precipitation (May-June) show that the growth rate of Scots pine on shingle fields is more affected by the amount of available water than by temperature. This is consistent with studies of climate-growth relationships in the eastern part of Fennoscandia (Linderholm 2001; Helama and Lindholm 2003; Linderholm et al. 2003), whereas studies in the western part have shown significant positive correlations with summer temperature (Briffa et al. 1992; Kaalela-Brundin 1999; Kirchhefer 2001; Linderholm et al. 2003).

The strongest climate-growth relationship $(r=0.66$, $p<0.0001$ ) was found between LW and the period 16 June-31 July. The correlation coefficients in this study suggest that LW formation in Scots pine trees in this area is influenced by the amount of available water as early as the middle part of June. The initiation of LW formation is not completely understood, but the impact of day length (Oleksyn et al. 1992) in combination with hormone concentrations has been investigated (Uggla et al. 2001). The day length decreases in the north from the Northern Hemisphere's summer solstice on June 21, which might explain why the correlation coefficient increases when the second half of June is added to the July precipitation (Table 2).

During the last decade several authors have reported that trees in higher latitudes have shown decreased temperature sensitivity since the mid-twentieth century. This has been referred to as the "divergence problem" and is of great importance for both forest growth and climate reconstructions (D'Arrigo et al. 2007). In a review of the topic D'Arrigo et al. (2007) summarized a number of possible explanations, such as moisture stress due to increased temperature, air pollution, and global

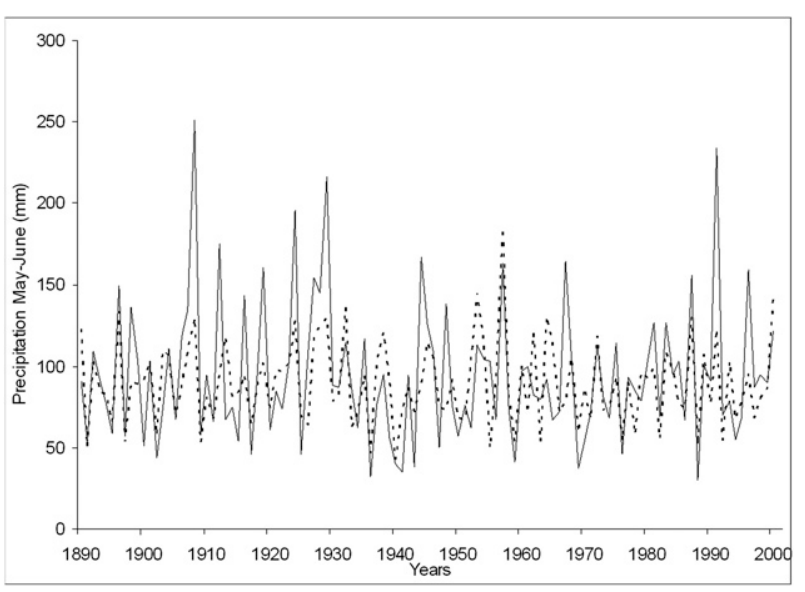

FIG. 3. Comparison between observed precipitation values at Härnösand station (solid line) and calculated values based on treering data (dashed line). 


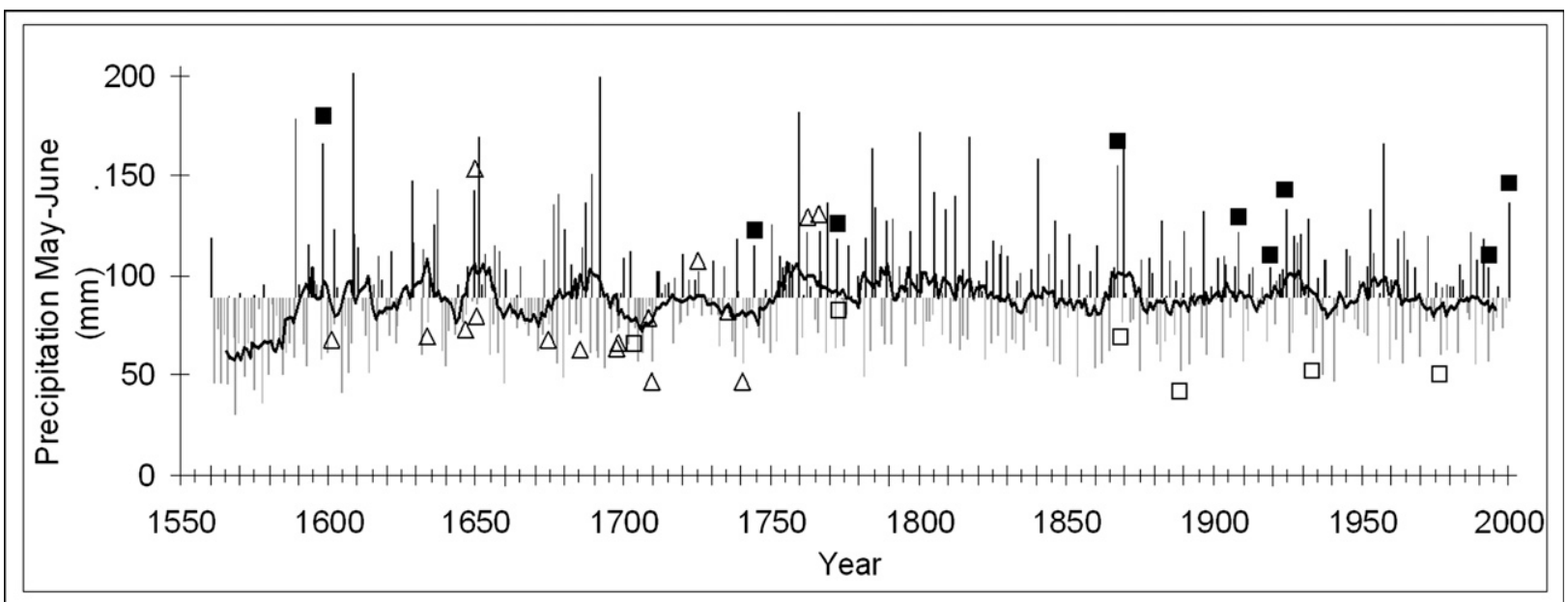

FIG. 4. Calculated precipitation May-June $(\mathrm{mm})$ given as deviation from mean. Gray bars show years with precipitation below average and black bars show years with precipitation above average. Information about $(\square)$ wet years, $(\square)$ dry years, and $(\triangle)$ bad harvest years from historical records is included in the diagram. The solid black line is the 10-yr running mean for reconstructed May-June precipitation.

dimming. The divergence problem has only been shown in temperature reconstructions and the lack of divergence in this study also supports the theory of moisture stress due to increased temperature. Indirectly, air pollution and global dimming may reduce solar radiation. Since a decrease in solar radiation also will result in a decreased evapotranspiration, the effect may be of less importance for plants in moisture-limited areas (Trenberth et al. 2007). This explains why the moisturelimited trees in this study do not show the same pattern as the Arctic trees limited by temperature. The conditions on the shingle fields are very stable over time since the very low water-holding capacity guarantees a dry environment.

When monthly climate data are used in long-term climate studies, it is important to remember that the growing season might not follow the calendar. A review of phenologic studies (i.e., the timing of recurrent biological phases) concluded that warmer winters and springs and earlier frost events are responsible for changes in the growing season (Linderholm 2006). During cold winters the ice cover is stable and the spring will be later in the coastal region than in the inland areas where the land warms up faster. Warmer winters will lead to less stable ice conditions in the Baltic Sea and an earlier start of the growing season. A warmer climate will increase evapotranspiration and change the relationship between precipitation and water supply for plants (Linderholm 2006). Therefore, it might be more accurate to look at the results as a reconstruction of available water during the early growing season instead of May-June precipitation.

\section{b. Precipitation reconstruction}

The correlation coefficients between observed precipitation at the meteorological stations and the precipitation reconstructed from tree rings (Fig. 5) indicate that the reconstruction is valid for the coastal part of central Sweden. Busuioc et al. (2001) defined four different regions with similar precipitation patterns (based on similarities in amount and seasonal distribution during the time 1890-1998). The region defined by correlations with the reconstruction follows almost the same northsouth limits as the "middle region" in their study (Fig. 5), but it is restricted to the eastern part of the country. This region was also identified by Busuioc et al. (2001) as a "center of high precipitation variability," and the yearto-year variation is high in the observed precipitation record. It is evident that the model is insufficient in years with exceptionally high or low precipitation (Fig. 3). Daily meteorological data show that the calculated precipitation (1961-2002) is underestimated during years with a few heavy rain falls, lasting typically one day. The ground has a very low water-holding capacity and the trees will not be favored by this high, but shortterm, amount of water. These years often have low May temperatures (such years were 1972, 1979-81, and 1993). The years with overestimated precipitation during the same period are dry in May and June and have most of the summer precipitation in July. There are also physiological limits for how wide and thin a tree ring can become (Fritts 1976; Schweingruber 1988). Analyses of observed data in Sweden have found an increase in precipitation since 1860 when the measurements started 


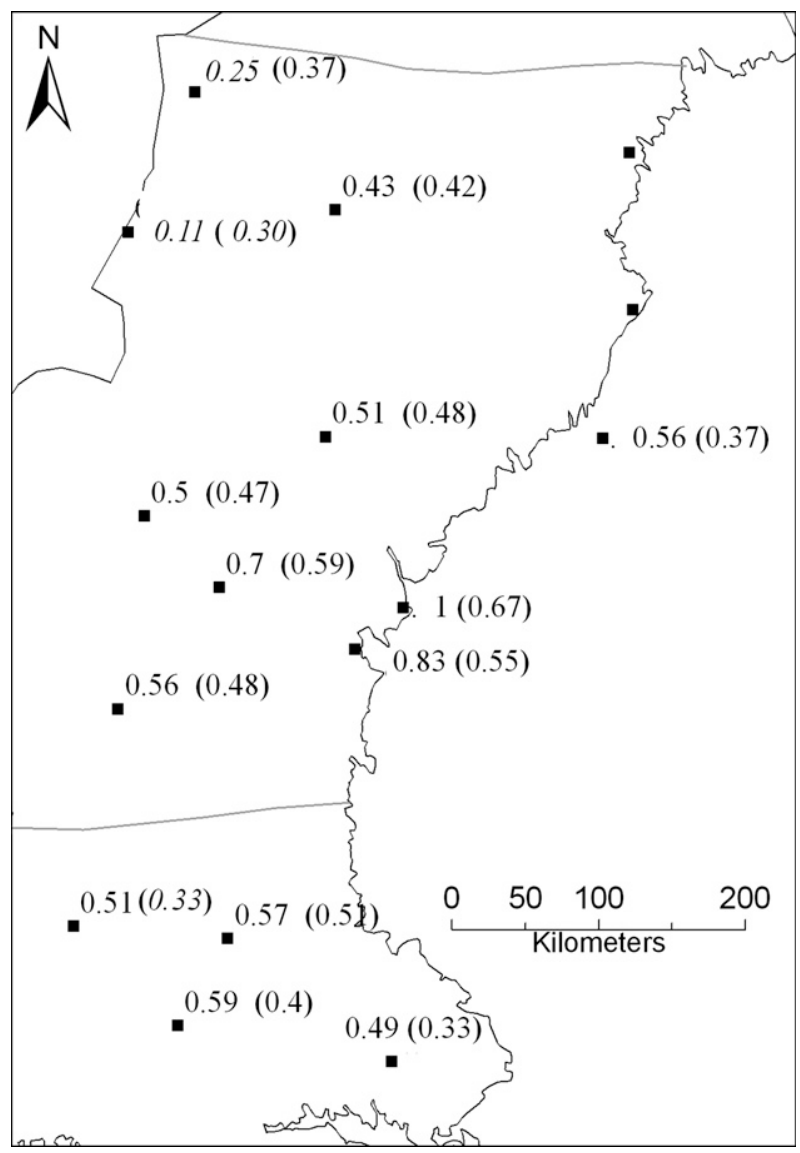

FIG. 5. Correlation coefficients between precipitation (MayJune) in Härnösand and other meteorological stations. Correlation coefficients for precipitation (May-June) at the meteorological station and the reconstructed precipitation for Härnösand are given in brackets. Numbers written in italics represent nonsignificant correlations $(p>0.001)$. Gray lines represent the regions defined by Busuioc et al. (2001).

(Busuioc et al. 2001; Alexandersson 2002). It is not possible to analyze trends or low-frequency variations in this study because of the standardization method and the use of RES.

The periods with precipitation below and above mean (Fig. 4) corroborate results from previous studies in Fennoscandia. Sander (2003) used varved sediments in the estuary of the river Angermanälven (close to the study area) to reconstruct the magnitude of the snowmelt flood, resulting from the accumulated winter precipitation over the entire catchment. Linderholm et al. (2004) reconstructed summer moisture in southern Sweden, but in this case the difference in precipitation regime explains the low resemblance. Helama and Lindholm (2003) used tree rings to reconstruct May-June precipitation in Finland (Fig. 6). They pointed to periods with precipitation above (1752-65) and below (1664-80) mean that corresponds well with our results. The year 1924 was described as a very wet year in line with our reconstruction.

The reconstructed precipitation data show a marked period between 1694 and 1751 with low variability and precipitation below mean. The period $1675-1715$ is often referred to as the Late Maunder Minimum (LMM) and is the coldest phase of the Little Ice Age (LIA). It was first recognized in the 1890s by the extremely low number of sun spots (Eddy 1976). This period also coincides with a reduced solar activity (Shindell et al. 2001; Zinke et al.2002) and enhanced volcanic activity (Shindell et al. 2003). The resemblance between the curves (Fig. 6) during this period is explained by Shindell et al. (2001) who stated that the reduced irradiance during this period may have caused a shift toward the low-index AO/NAO state. Luterbacher et al. (2001) and Bauer et al. (2002) have also shown that springs and summers in northwest Europe were dry and cold during this period.

The May-June precipitation reconstruction was compared with indices explaining $\mathrm{AO}$ and NAO, respectively. There were no significant correlations between year-to-year variations in reconstructed precipitation and NAO (Cook et al. 2002) or AO (D'Arrigo et al. 2003 ) indices. However, periods with precipitation above and below mean showed some similarities mostly with the AO curve. A period with AO index above mean corresponds to relatively high precipitation. During the positive AO phase, the winds tighten around the high Arctic, locking cold air in place. At the same time the higher pressure at midlatitudes drives North Atlantic storms farther north, bringing warm and wet weather to Scandinavia. During the negative phase, the low pressure and the winds are weaker, allowing cold, dry continental air to reach southward into Europe, North America, and Asia. Wibig (1999) stated that precipitation on Baltic shores seems to be related to local circulation more than to global patterns, whereas Busuioc et al. (2001) argued that changes in the Swedish precipitation regime are likely due to changes in large-scale circulation. The effect of NAO on Swedish precipitation and temperature has been shown by Busuioc et al. (2001), Hurrell et al. (2003), Uvo (2003), and others but has mainly been restricted to the winter months. This result is in line with result from Omstedt and Chen (2001) who found that the ice extent in the Baltic Sea was fairly well correlated with the NAO. The historical information and the large number of different proxy data increase the reliability of the information about the cold and dry periods during the LMM (Wanner et al. 1995; Houghton et al. 2001; Zinke et al. 2002). In this case the historical records serve as an independent 


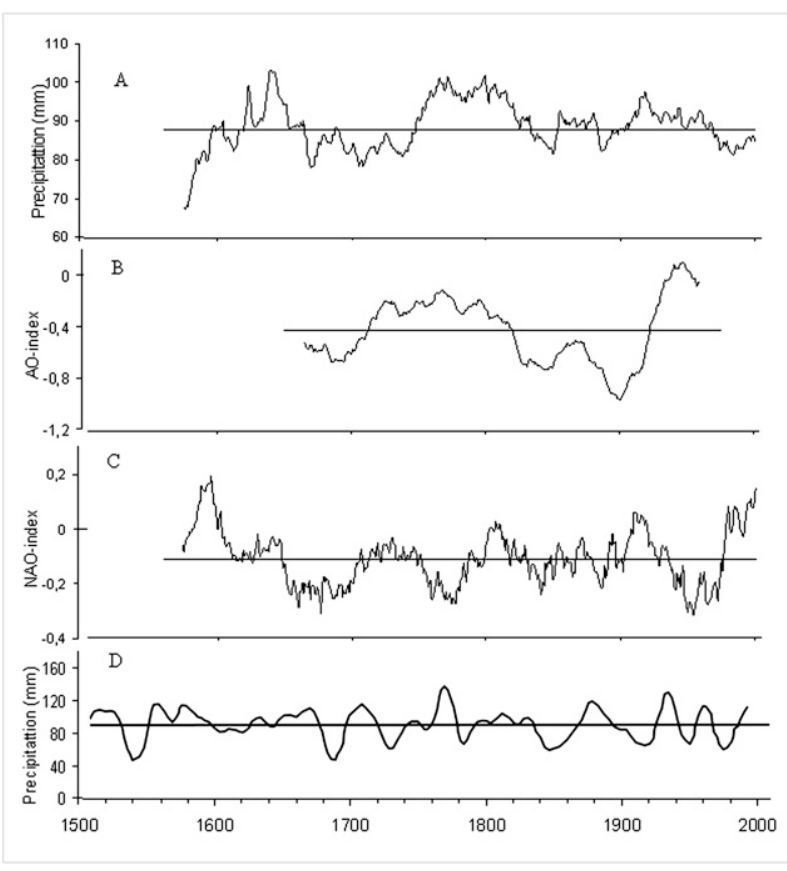

FIG. 6. Ten-yr running mean for reconstructed (a) May-June precipitation, (b) AO index [June-August (JJA); D'Arrigo et al. 2003], (c) NAO index [December-February (DJF); Cook et al. 2002], and (d) reconstructed early summer precipitation (28-yr cubic spline) in Finland (Helama and Lindholm 2003).

control of the reconstruction and information from historical documents confirms the results from the treering reconstruction (Fig. 4).

\section{Conclusions}

Scots pine trees growing on shingle fields in mideast Sweden are mainly influenced by precipitation in May and June and correlates well with EW and RW chronologies. LW widths are better correlated with July precipitation. The partial least square regression model explained $45 \%$ of the May-June precipitation variability when EW and LW were used separately. The reconstruction model underestimated the highest precipitation values and overestimated the lowest. The calculated May-June precipitation applies to a relatively large region along the east coast of central Sweden. There was a marked period between 1694 and 1751 with precipitation below mean and low variability. This may correspond to the Late Maunder Minimum, which is a known cold and dry period when the large-scale circulations $\mathrm{AO}$ and NAO were in a negative phase and cold, dry continental air dominated in this area. Knowledge about past climate facilitates understanding of complex climatic systems. The results from this study conclude that important information about precipitation variations can be ex- tracted from trees growing on extremely dry sites even in areas where trees are generally not limited by water supply. Since precipitation is highly variable at both spatial and temporal scales, a network of long reconstructions is needed to describe historical precipitation patterns in large regions.

Acknowledgments. This research was supported by the Kempe Foundations. We thank N. Dahlström for valuable discussions and assistance in the field, M. Berglund and P. Cherubini for valuable comments on the manuscript, and the County Administration Board of Västernorrland for granting permission to collect samples in the nature reserves Vårdkasmalen and Smitingen. We are grateful to three journal reviewers for valuable comments on the manuscript.

\section{REFERENCES}

Alexandersson, H., 2002: Temperatur och nederbörd i Sverige 1860-2001 (Temperature and precipitation in Sweden 1860 2001). Meteorology Rep. 104, Swedish Meteorological and Hydrological Institute, $28 \mathrm{pp}$.

Bakke, J., S. O. Dahl, Ø. Paasche, R. Løvlie, and A. Nesje, 2005: Glacier fluctuations, equilibrium-line altitudes and palaeoclimate in Lyngen, northern Norway during the Lateglacial and Holocene. Holocene, 15, 518-540.

Bauer, E., M. Claussen, A. Huenerbein, and V. Brovkin, 2002: Assessment of climate forcing contributing to the Late Maunder Minimum. Extended Abstracts, Spring Meeting, Washington, DC, Amer. Geophys. Union, Abstract GC41B-04.

Bergström, S., 1994: Sveriges Hydrologi: Grundläggande Hydrologiska Förhållanden (Sweden's Hydrology: Fundamental Hydrological Conditions). Swedish Meteorological and Hydrological Institute and Svenska Hydrologiska Rådet, 138 pp.

Biondi, F., and K. Waikul, 2004: DENDROCLIM2002: A C ++ program for statistical calibration of climate signals in treering chronologies. Comput. Geosci., 30, 303-311.

Bjune, A. E., J. Bakke, A. Nesje, and H. J. B. Birks, 2005: Holocene mean July temperature and winter precipitation in western Norvay inferred from palynological and glaciological lakesediment proxies. Holocene, 15, 177-189.

Borgmark, A., and K. Schoning, 2005: A comparative study of peat proxies from two eastern central Swedish bogs and their relation to meteorological data. J. Quat. Sci., 21, 109-114.

Brázdil, R., C. Pfister, H. Wanner, H. von Storch, and J. Luterbacher, 2005: Historical climatology in Europe: The state of the art climatic change. Climatic Change, 70, 363-430.

Briffa, K. R., 1995: Interpreting high-resolution proxy climate data: The example of dendroclimatology. Analysis of Climate Data Variability: Applications of Statistical Techniques, H. von Storch and A. Navarra, Eds., Springer Verlag, 77-94. , and P. D. Jones, 1990: Basic chronology statistics and assessment. Methods of Dendrochronology: Application in the Environmental Sciences, E. R. Cook and L. A. Kairiukstis, Eds., Kluwer Academic Publications, 104-123.

, — - T. S. Bartholin, D. Eckstein, F. H. Schweingruber, W. Karlén, P. Zetterberg, and M. Eronen, 1992: Fennoscandian 
summers from AD 500: Temperature changes on short and long timescales. Climate Dyn., 7, 111-119.

Burman, F., 1930: Fale Burmans Anteckningar om Jämtland i Urval (Fale Burman's Selected Notes on Jämtland). Jämtlands Läns Fornskriftsällskap, $136 \mathrm{pp}$.

Busuioc, A., D. Chen, and C. Hellström, 2001: Temporal and spatial variability of precipitation in Sweden and its link with the large scale atmospheric circulation. Tellus, 53A, 348-367.

Cook, E. R., 1985: A time series analysis approach to tree ring standardization. Ph.D. thesis, The University of Arizona, 175 pp.

—, and L. A. Kairiukstis, Eds., 1990: Methods of Dendrochronology: Application in the Environmental Sciences. Kluwer Academic, 394 pp.

—_ and P. J. Krusic, cited 2005: Program ARSTAN: A tree-ring standardization program based on detrending and autoregressive time series modeling, with interactive graphics. Lamont Doherty Earth Observatory of Columbia University. [Available online at http://www.ldeo.columbia.edu/res/fac/trl/ public/publicSoftware.html.]

—, R. D. D'Arrigo, and M. E. Mann, 2002: A well-verified, multiproxy reconstruction of the winter North Atlantic Oscillation index since A.D. 1400. J. Climate, 15, 1754-1764.

D'Arrigo, R. D., E. R. Cook, M. E. Mann, and G. C. Jacoby, cited 2003: Warm season Arctic oscillation reconstructions, 1650 1978 AD. International Tree-Ring Data Bank, IGBP PAGES/ World Data Center for Paleoclimatology Data Contribution Series 003-045, NOAA/NGDC Paleoclimatology Program. [Available online at http://gcmd.nasa.gov/records/GCMD_ NOAA_NCDC_PALEO_2003-045.html.]

- R. Wilson, B. Liepert, and P. Cherubini, 2007: On the 'divergence problem' in northern forests: A review of the treering evidence and possible causes. Global Planet. Change, 60, 289-305.

De Jong, R., S. Björck, L. Björkman, and L. B. Clemmensen, 2006: Storminess variations during the last 6500 years as reconstructed from an ombrotrophic bog in Halland, SW Sweden. J. Quat. Sci., 21, 905-919.

Eddy, J. A., 1976: The Maunder Minimum. Science, 192, 1189-1202.

Eklund, B., 1954: Årsringsbreddens klimatiskt betingade variation hos tall och gran inom norra Sverige åren 1900-1944 (The climatically induced variation of tree-ring width for pine and spruce in northern Sweden during 1900-1944). Medd. Statens Skogsforskningsinst. (Swed.), 44, 1-150.

Eriksson, J. V., 1919: Översvämningarna i mellersta Norrlands kusttrakter i maj 1919 (The floods in the coastal areas of central Norrland in May 1919). Ymer, 1919, 181-186.

Erlandsson, S., 1936: Dendrochronological studies. Stockholm's College Geochronological Institute Rep. 23, Uppsala, Sweden, $116 \mathrm{pp}$.

Fritts, H. C., 1976: Tree Rings and Climate. Academic Press, 567 pp.

— , and J. Guiot, 1990: Methods of calibration, verification and reconstruction. Methods of Dendrochronology: Applications in the Environmental Sciences, E. R. Cook and L. A. Kairiukstis, Eds., Kluwer Academic, 163-217.

Gimmi, U., J. Luterbacher, J. Pfister, and H. Wanner, 2007: A method to reconstruct long precipitation series using systematic descriptive observations in weather diaries: The example of the precipitation series for Bern, Switzerland (1760-2003). Theor. Appl. Climatol., 87, 185-199.

Grove, J. M., and R. Switzur, 1994: Glacial geological evidence for the Medieval Warm Period. Climatic Change, 26, 143-169.
Grudd, H., 2006: Tree rings as sensitive proxies of past climate change. Ph.D. thesis, Stockholm University, 75 pp.

Gunnarson, B. E., and H. W. Linderholm, 2002: Low-frequency summer temperature variation in central Sweden since the tenth century inferred from tree rings. Holocene, 12, $667-671$.

Hansen, J., M. Sato, R. Ruedy, K. Lo, W. David, D. W. Lea, and M. Medina-Elizade, 2006: Global temperature change. Proc. Natl. Acad. Sci. USA, 103, 14 288-14 293.

Helama, S., and M. Lindholm, 2003: Droughts and rainfall in southeastern Finland since AD 874, inferred from Scots pine ringwidths. Boreal Environ. Res., 8, 171-183.

,,-- M. Timonen, J. Meriläinen, and M. Eronen, 2002: The supra-long Scots pine tree-ring record for Finnish Lapland: Part 2, interannual to centennial variability in summer temperatures for 7500 years. Holocene, 12, 681-687.

Högman, H., cited 2005: Agricultural yields and years of famineSweden. [Available online at www.algonet.se/ hogman/ swegen.htm.]

Holmes, R. L., R. K. Adams, and H. C. Fritts, 1986: Tree-ring chronologies of western North America: California, eastern Oregon and northern Great Basin with procedures used in the chronology development work including users' manuals for computer programs COFECHA and ARSTAN. Laboratory of Tree-Ring Research, The University of Arizona, $182 \mathrm{pp}$.

Houghton, J. T., Y. Ding, D. J. Griggs, M. Noguer, P. J. van der Linden, X. Dai, K. Maskell, and C. A. Johnson, Eds., 2001: Climate Change 2001: The Scientific Basis. Cambridge University Press, 881 pp.

Hurrell, J. W., cited 1995: NAO index data. Climate Analysis Section, NCAR, Boulder, Colorado. [Available online at http:// www.cgd.ucar.edu/cas/jhurrell/indices.data.html\#naostatmon.]

—, Y. Kushnir, M. Vibe, and G. Ottersen, 2003: An overview of the North Atlantic Oscillation. The North Atlantic Oscillation: Climatic Significance and Environmental Impact, Geophys. Monogr., Vol. 134, Amer. Geophys. Union, $1-35$.

Jansen, E., and Coauthors, 2007: Paleoclimate. Climate Change 2007: The Physical Science Basis, S. Solomon et al., Eds., Cambridge University Press, 433-497.

Jones, P. D., K. R. Briffa, and S. F. B. Tett, 1998: High-resolution palaeoclimatic records for the last millennium: Interpretation, integration and comparison with general circulation model control-run temperatures. Holocene, 8, 455-471.

Jonsson, A., 2005: The Governors of Northern Sweden and the State Formation Process, 1634-1769 (in Swedish with English summary). Umeå University, 319 pp.

Kaalela-Brundin, M., 1999: Climatic information from tree-rings of Pinus sylvestris L. and a reconstruction of summer temperatures back to AD 1500 in Femundsmarka, eastern Norway, using partial least squares regression (PLS) analysis. Holocene, 9, 59-77.

Karlén, W., 1973: Holocene glacier and climatic variations, Kebnekaise mountains, Swedish Lapland. Geogr. Ann., 55A, 29-63.

Kastellet, E., A. Nesje, and E. S. Pedersen, 1998: Reconstructing the palaeoclimate of Jæren, Southwestern Norway, for the period 1821-1850, from historical documentary records. Geogr. Ann., 80A, 51-65.

Kirchhefer, A. J., 2001: Reconstruction of summer temperatures from tree-rings of Scots pine (Pinus sylvestris L.) in coastal northern Norway. Holocene, 11, 41-52. 
Larsson, L.- $\AA$., 2006: Namdoe tree-ring data. SWED302 International Tree Ring Data Bank (ITRDB), NOAA/NCDC Paleoclimatology Program. [Available online at ftp://ftp.ncdc. noaa.gov/pub/data/paleo/treering/measurements/europe/ swed302.rwl.]

Linderholm, H. W., 2001: Climatic influence on Scots pine growth on dry and wet soils in the central Scandinavian mountains, interpreted from tree-ring widths. Silva Fenn., 35, 415-424.

- 2006: Growing season changes in the last century. Agric. For. Meteor., 137, 1-14.

— , and B. E. Gunnarson, 2005: Summer climate variability in west-central Fennoscandia during the last 3600 years. Geogr. Ann., 87A, 231-241.

— , and T. Molin, 2005: Early nineteenth century drought in east central Sweden inferred from dendrochronological and historical archives. Climate Res., 29, 63-72.

— A. Moberg, and H. Grudd, 2002: Peatland pines as climate indicators? A regional comparison of the climatic influence on Scots pine growth in Sweden. Can. J. For. Res., 32, $1400-1410$.

_ B. B. Solberg, and M. Lindholm, 2003: Tree-ring records from central Fennoscandia: The relationship between tree growth and climate along a west-east transect. Holocene, 13, $887-895$.

_ variability in east central Sweden since the mid-eighteenth century recorded in tree rings. Geogr. Ann., 86A, 277-287.

Lindholm, M., and M. Eronen, 2000: A reconstruction of midsummer temperatures from ring-widths of Scots pine since AD 50 in Northern Fennoscandia. Geogr. Ann., 82A, 527-535.

-, H. Lehtonen, T. Kolström, J. Meriläinen, M. Eronen, and M. Timonen, 2000: Climatic signals extracted from ring-width chronologies of Scots pines from the northern, middle and southern parts of the boreal forest belt in Finland. Silva Fennica, 34, 317-330.

Linsley, B. K., R. B. Dunbar, G. M. Wellington, and D. A. Mucciarone, 1994: A coral-based reconstruction of intertropical convergence zone variability over Central America since 1707. J. Geophys. Res., 99, 9977-9994.

Lundmark, J. E., 1986: Skogsmarkens Ekologi. Ståndortsanpassat Skogsbruk, Del 1-Grunder (Ecology of the Forest Land. Habitat Adapted Forestry, Part 1-Fundamentals). Swedish Forestry Board, $158 \mathrm{pp}$.

Lundqvist, J., 1987: Beskrivning till jordartskarta över Västernorrlands län och förutvarande Fjällsjö k:n (Description to Soil Type Map over Västernorrland Province and the Former Fjällsjö Municipality). Geological Survey of Sweden, 270 pp.

Luterbacher, J., R. Rickli, E. Xoplaki, C. Tinguely, C. Beck, C. Pfister, and H. Wanner, 2001: The Late Maunder Minimum (1675-1715): A key period for studying decadal scale climatic change in Europe. Climatic Change, 49, 441-462.

Mann, M. E., R. S. Bradley, and M. K. Hughes, 1998: Global-scale temperature patterns and climate forcing over the past six centuries. Nature, 392, 779-787.

National Research Council, 2006: Surface Temperature Reconstructions for the Last 2,000 Years. The National Academies Press, $160 \mathrm{pp}$.

Nesje, A., 2005: Briksdalsbreen in western Norway: AD 1900/2004 frontal fluctuations as a combined effect of variations in winter precipitation and summer temperature. Holocene, 15, 1245-1252.

O'Brien, S. R., P. A. Mayewski, L. D. Meeker, D. A. Meese, M. S. Twickle, and S. I. Whitlow, 1995: Complexity of Holo- cene climate as reconstructed from a Greenland ice core. Science, 270, 1962-1964.

Oleksyn, J., M. G. Tjoelker, and P. B. Reich, 1992: Growth and biomass partitioning of populations of European Pinus sylvestris L. under simulated $50^{\circ}$ and $60^{\circ} \mathrm{N}$ daylengths: Evidence for photoperiodic ecotypes. New Phytol., 120, 561-574

Omstedt, A., and D. Chen, 2001: Influence of atmospheric circulation on the maximum ice extent in the Baltic Sea. J. Geophys. Res., 106, 4493-4500.

Pfister, C., and Coauthors, 1999: Documentary evidence on climate in sixteenth-century Europe. Climatic Change, 43, 55-110.

Post, J. D., 1984: Climatic variability and the European mortality wave of the early 1740s. J. Interdiscip. Hist., 15, 1-30.

Sander, M., 2003: Climatic signals and frequencies in the Swedish time scale, river Ångermanälven, Central Sweden. Ph.D. thesis, Lund University, $130 \mathrm{pp}$.

Schweingruber, F. H., 1988: Tree Rings: Basics and Applications of Dendrochronology. Reidel, 276 pp.

— , cited 2005: Dendrochronological data. SWED023W International Tree Ring Data Bank (ITRDB), NOAA/NCDC Paleoclimatology Program. [Available online at ftp://ftp. ncdc.noaa.gov/pub/data/paleo/treering/measurements/europe/ swed023w.rwl.]

Shindell, D. T., G. A. Schmidt, M. E. Mann, R. Rind, and A. Waple, 2001: Solar forcing of regional climate change during the Maunder Minimum. Science, 294, 2149-2152.

$\longrightarrow,-$, R. L. Miller, and M. E. Mann, 2003: Volcanic and solar forcing of climate change during the preindustrial era. J. Climate, 16, 4094-4107.

SMHI, 1924: Årsbok 1924 (Yearbook 1924). Swedish Meteorological and Hydrological Institute.

_ 1993: Väder och Vatten (Weather and Water). Swedish Meteorological and Hydrological Institute.

Solomon, S., and Coauthors, 2007: Technical summary. Climate Change 2007: The Physical Sciences Basis, S. Solomon et al., Eds., Cambridge University Press, 19-91.

Törnlöv, J., 2005: En studie av klimatrelaterade data i svenska 1700-tals dokument: kan historiska dokument från mellersta Norrland användas för rekonstruktion av klimatet under Lilla Istidens senare del? (A study of climate related data in Swedish 18th century documents: Can historical documents from central Norrland be used for reconstruction of climate during the latter part of the Little Ice Age?). University essay, Mid Sweden University, 42 pp.

Trenberth, K. E., and Coauthors, 2007: Observations: Surface and atmospheric climate change. Climate Change 2007: The Physical Science Basis, S. Solomon et al., Eds., Cambridge University Press, 235-336.

Tuomenvirta, H., A. Drebs, E. Forland, O. E. Tveito, H. Alexandersson, E. V. Laursen, and T. Jonsson, 2001: Nordklim data set 1.0-description and illustrations. Norwegian Meteorological Institute Rep. 08/01, 27 pp.

Uggla, C., E. Magel, T. Moritz, and B. Sundberg, 2001: Function and dynamics of auxin and carbohydrates during earlywood/latewood transition in Scots pine. Plant Physiol., 125, 2029-2039.

Uvo, C. B., 2003: Analysis and regionalization of northern European winter precipitation based on its relationship with the North Atlantic oscillation. Int. J. Climatol., 23, 1185-1194.

Wanner, H., and Coauthors, 1995: Wintertime European circulation patterns during the Late Maunder Minimum 
cooling period (1675-1704). Theor. Appl. Climatol., 51, Zillén, L., 2003: Setting the Holocene clock using varved 167-175.

Wibig, J., 1999: Precipitation in Europe in relation to circulation patterns at the $500 \mathrm{hPa}$ level. Int. J. Climatol., 19, 253-269.

Wigley, T. M. L., K. R. Briffa, and P. D. Jones, 1984: On the average value of correlated time series, with applications in dendroclimatology and hydrometeorology. J. Appl. Meteor., 23, 201-213. lake sediments in Sweden. Ph.D. thesis, Lund University, $37 \mathrm{pp}$.

Zinke, J., and Coauthors, 2002: Evidence for the climate during the Late Maunder Minimum from proxy data available within KIHZ. The Climate in Historical Times: Towards a Synthesis of Holocene Proxy Data and Climate Models, H. Fischer et al., Eds., Springer Verlag, 397-414. 